Western University

Scholarship@Western

Political Science Publications

Political Science Department

Spring 1999

\title{
The Principles of Liberal Internationalism According to Lester Pearson
}

Erika Simpson

Political Science, simpson@uwo.ca

Follow this and additional works at: https://ir.lib.uwo.ca/politicalsciencepub

Part of the Political Science Commons

Citation of this paper:

Simpson, Erika, "The Principles of Liberal Internationalism According to Lester Pearson" (1999). Political Science Publications. 87. https://ir.lib.uwo.ca/politicalsciencepub/87 


\title{
The Principles of Liberal Internationalism According to Lester Pearson
}

\author{
Erika Simpson
}

\begin{abstract}
Liberal internationalism remains the dominant perspective of those who study Canadian foreign policy, many of whom evoke the "Golden Age" of Canadian diplomacy under Lester B. Pearson. This article analyses Pearson's own ideas about the approach that Canada should take on the world stage and reveals recurring themes in his thinking. Analysis of these ideas imparts some general guidelines for conducting Canadian foreign policy. Primary documentary material in the Public Archives of Canada, interviews with Pearson's son and colleagues as well as Pearson's own writing are used to interpret the central elements of his belief system and assess his contribution to liberal internationalism. This article increases understanding of the effect of belief systems on foreign policy-making and of the impact of the liberal ideology that permeated North American culture during Pearson's era.
\end{abstract}

L'internationalisme libéral demeure la perspective dominante parmi celles et ceux qui étudjent la politique étrangère canadienne, et nombreux sont celles et ceux qui aiment revenir sur l'Âge d'or de la diplomatie canadienne sous Lester B. Pearson. Cet article analyse les idées de Pearson sur l'approche que le Canada devrait adopter dans le cadre de la scène mondiale. Il en ressort que certains "thèmes" dominaient sa pensée et ceux-ci permettent de tracer quelques grandes lignes générales guidant la conduite de la politique étrangère canadienne. Pour interpréter les éléments centraux du système de pensée de Pearson, cette étude utilise des documents de première main tirés des archives publiques du Canada, des entretiens avec le fils de Pearson et ses collègues, ainsi que ses propres écrits et réflexions publiques. La contribution originale de cet article touche à l'identification de thèmes dominants et d'idées générales dans la propre pensée de Pearson. Distiller les thèmes auxquels P'earson faisait continuellement référence permet d'apporter une meilleure appréciation de sa contribution concrète à l'émergence de l'internationalisme libéral. Cette étude contibue aussi à la littérature croissante sur l'effet des systèmes de pensée sur la politique étrangère tout en offrant une meilleure compréhension de l'impact prépondérant de l'idéologie libérale qui imprégnait la culture candienne sous l'ère pearsonienne. 
One of the truest things that one of his closest friends who knew him much better than I did, Hume Wrong, ever said about him was that Pearson never seemed to act on grounds of rationally arrived principles which could be stated and clearly expressed as motivation. He said that, to understand Pearson, you have to think of him as a sort of a Houdini: you tie him up, stick him in a mess, and without telling you how, why, or when, he'll get himself out and in the process help all the others who are involved.

George Ignatieff "

\section{Introduction: Pearson's Career}

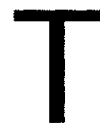

he career of Lester Bowles Pearson is important in the study of Canadian foreign and defence policy because of his lifelong effort to secure international peace and security. Mike Pearson rose through the ranks of the foreign service to become prime minister. After serving in the First World War and then lecturing in history at the University of Toronto, he joined the Department of External Affairs (now the Department of Foreign Affairs and International Trade) in 1928. He moved rapidly through the ranks of the diplomatic service, acting as head of the Canadian delegation to the League of Nations, as a diplomat in London from 1935 to 1941 and as Canada's first ambassador to the United States in 1944. He became the deputy minister or undersecretary of state for External Affairs in September 1946. In 1948, at the behest of then Prime Minister Mackenzie King and of Louis St. Laurent, he entered Parliament and served as the minister or secretary of state for External Affairs from 1948 to 1957. He then succeeded St. Laurent as leader of the Liberal Party and was the leader of the Opposition during the Diefenbaker era. In 1963 he became prime minister, serving in that capacity until replaced by Pierre Trudeau in 1968.

As prime minister, Pearson is remembered for the introduction of the Maple Leaf flag, the success of the centennial year, the introduction of social security plans such as the Canada Pension Plan and medicare, and the steps he took to make French Canadians more at home within Confederation. ${ }^{2}$ Canadian's most enduring memory of Mike Pearson, however, is of his role as a skilful, diplomatic mediator on the world stage. During many world crises he played the role of negotiator and, when not involved in resolving conflicts, he worked to build and improve institutions such as the United Nations (UN), the Commonwealth and the North Atlantic Treaty Organisation (NATO). A measure of Pearson's contribution to alleviating world tension was seen by the decision to award him with the Nobel Peace Prize in 1957 for his role in establishing UN peacekeeping forces during the Suez crisis. 


\section{Pearson as Chief Practitioner of the Liberal Internationalist Approach}

Because of his prominent international role, Pearson is considered the chief exponent and practitioner of the liberal internationalist approach to handling Canada's foreign policy. What are the aims and underlying philosophical tenets of this approach? Over the years, analysts have studied the works of diplomats from the golden age of Canadian diplomacy (e.g. books by John Holmes, Hume Wrong, Escott Reid, and commentary by Louis St. Laurent, O.D. Skelton and L.C. Christie), to discern the concepts that informed this doctrine. ${ }^{+}$These works by the original practitioners of liberal internationalism include careful historical analysis yet are essentially political memoirs from which it is difficult to derive a theory. ${ }^{5}$ Indeed, upon assuming office, Prime Minister Pierre Elliott Trudeau called for a comprehensive review of the foreign policy review process because he believed that under Pearson policy-making had been characterised by a reactive and ad hoc approach to international events, rather than by adherence to a coherent set of policies based on national interests.

Nevertheless, Pearson's comments on Canadian foreign and defence policy are worth analysing, if only because the dominant themes in Pearson's thinking formed the core of liberal internationalist theory and practice. His son, Geoffrey Pearson, says that his father "didn't have longterm blueprints" and "wasn't a philosopher." This paper, however, argues that certain themes underlay Pearson's thinking and that they demonstrate some general guidelines for conducting Canadian foreign policy. Such themes are apparent in his memoirs, speeches and personal papers. Primary documentary material in the Public Archives of Canada and interviews with Pearson's son and colleagues are used, in addition to Pearson's own written and public record, to interpret the central elements of Pearson's belief system. ${ }^{8}$ This analysis may lead to greater appreciation of Pearson's contribution to the emergence of the liberal internationalism perspective. This article is also part of the growing literature on the effect of belief systems on Canadian foreign policy making" and provides a deeper understanding of the impact of the liberal ideology that permeated Canadian culture during Pearson's era. ${ }^{i \prime}$

\section{To Play A Middle Power Role}

Before Lester Pearson became deputy minister of External Affairs in 1946, Canada was perceived as a secondary power serving as a bridge or linchpin between Britain and the United States." The opinion that Canada should play a role as a middlepower, however, became common among civil servants in the department during Pearson's tenure. ${ }^{12}$ Pearson saw Canada as part of a bipolar nuclear world dominated by two great powers and populated by many middle and small powers. ${ }^{13}$ While the war had 
weakened many countries, it had left Canada economically strong and physically intact, Pearson believed. "It was this temporary situation," he wrote "and our utilization of it, that made our international policies and actions more forthright than they would otherwise have been." ${ }^{\prime \prime}$ The unofficial practice became one where Pearson and his fellow diplomats referred frequently to Canada's role as a middle power. According to John Holmes, who worked with Pearson in the department and eventually became assistant undersecretary of external affairs, playing the role of middle power meant that Canadian diplomats tried to act as "middlemen" for the superpowers at the UN and other international bodies, to obtain sponsors for compromise resolutions, to lobby so as to avoid dangerous confrontation and to seek, through the auspices of international organisations, to reduce tension among nations. In Holmes's words, the middlepower mediator role "fitted our philosophy."

One problem, however, was that the term middle power implied a number of characteristics including, at various times, size, economic power and a nation's ability to contribute to the UN. ${ }^{17}$ Gradually the term began to take on more and more characteristics, including usefulness as an intermediary and population size. Questions were raised about whether the adjective referred to a country's middling strength in military and economic fields, its geographic location or to its position on the ideological spectrum between two extreme positions. Eventually it became difficult for some of the original employers of the term to decide which countries were middle powers, and what role a middle power should play. ${ }^{18}$ In later years, Holmes worked hard to understand the subtleties of the term, but Pearson never tackled the problem of defining a middle power and its role, although he continued to include Canada among the middle powers."

\section{To Promote the Principle of Functionalism}

In the 1940 s and 1950s, the Canadian government's approach to representation in international organisations was strongly influenced by the organising principle of functionalism. This principle was not a Canadian invention but it gradually acquired a Canadian flavour. ${ }^{2(1)}$ Its central concept was that decision-making responsibility had to be shared, and that it should be shared by those who were most capable of contributing to the issue at hand. ${ }^{2}$ Canadian diplomats, such as Lester Pearson, Hume Wrong and Norman Robertson, argued in New York, Washington and London that states should be entitled to more decision-making power and greater responsibilities in international organisations like the UN when their capabilities and interests were strongly reflected in the issues under discussion. In concrete terms, they implied that Canada should have a strong voice and a seat at the table whenever it had an interest or comparative advantage - as Canada had then, for example, in such 
matters as the management of international trade, the production and distribution of food, the regulation of civil aviation and the harnessing of atomic power.

When the Canadian argument for functional representation was made in the mid 1940s, Canada was the largest supplier of food and raw materials to the war effort, next to the Americans. Indeed, the credit for first applying the concept to Canadian concerns must be given to Prime Minister Mackenzie King who argued in 1943 that representation in the new international institutions set up after the war should be determined on a functional basis. Only those countries that had the greatest contribution to make to the object in question should be admitted to full membership. ${ }^{22}$ Pearson somewhat modified the term and, in his memoirs, refers to its utility in handling problems of representation and responsibility. In his view, the concept of functionalism could be used to justify Canadian efforts to ensure that "membership on bodies and committees would include those, but only those, who had a very real and direct interest in the work and could make a contribution to it." "Thus Canadian diplomats justified classifying problems by issue area (e.g. economic versus security issues, low-politics versus high-politics) and attempted to assign special responsibilities and status to countries in the organisations and activities for which they were especially fitted, or in which they had special interests. ${ }^{24}$

The extent to which the principle of functionalism served Canadian interests is difficult to appreciate, unless the concept is placed in the context of its time. Immediately after the war, Pearson and the diplomats in the Department of External Affairs were concerned about how Canada could exert greater influence at the international level and tried to forestall the expansion of superpower hegemony into every policy area. ${ }^{25}$ In this they were not serving Canadian interests alone. They thought they could ensure that the middle and smaller powers would have reasonable parts to play in the new international order. ${ }^{26}$ By the early 1950 s, nevertheless, the language of functionalism had disappeared from Pearson's vocabulary, only to re-emerge later as one of the fundamental tenets of the theory of liberal internationalism. ${ }^{2-}$ It is not clear why Pearson ceased referring to this concept. It may have been because it conflicted with liberal, democratic principles, particularly Pearson's own concept of a middle power. The idea that any country could be, in turn, a major, middle or minor power on some issues (e.g. food production, civil aviation) may have seemed at odds with the notion that there was a standard role middle powers could play. While Pearson advanced the middle power argument, in part as a calculated way to enhance international security by restraining the great powers, he used the functional principle when other low-politics issues arose. It remains unclear if and when Pearson recognised that these concepts were not entirely complementary but Pearson's close colleague John Holmes offers a similar explanation for the demise of the functional doctrine among Canadian diplomats. ${ }^{28}$ 


\section{To Mediate Conflict}

Although the role of mediator was frequently thrust upon the middle powers during crises at the UN, Lester Pearson often actively sought it for Canada. ${ }^{29}$ In fact, he became renowned for his efforts to present a peace programme to the General Assembly so as to consolidate the Korean situation; for his initiative in urging the Americans not to use nuclear weapons in Korea; for his attempt to relay information about Chinese intentions to the United States after UN forces had moved beyond the 38th parallel; for his work on the ceasefire committee for Indochina; for his collaboration with India and Poland on the International Supervisory Commissions in IndoChina; for his role in proposing and implementing peacekeeping forces during the Suez crisis; and for his successful effort to open up membership of the United Nations to all the world's nations. Why did Pearson so frequently act on behalf of Canada to solve the crises that beset the United Nations? Why did he struggle to obtain compromises and solutions to political problems that often did not directly involve Canada?

Pearson often referred in his memoirs to the horrors of battle, which he had witnessed during the First World War, as the main reason for his overarching belief that any compromise was better than armed conflict. ${ }^{3 \prime}$ The reasons for his belief that Canada should act as a mediator are, however, more complex than that and not clearly delineated in his memoirs or speeches. A close reading of Pearson's own account of his negotiating efforts reveals his desire to improve gradually the existing world order. During the Suez crisis in 1956, for example, it seemed imperative to him that Canada strive to implement the first UN peacekeeping forces because war "threatened to destroy Anglo-American co-operation, to split the Commonwealth, and brand our two mother countries, Britain and France, as aggressors." ${ }^{31}$ Pearson instructed the Canadian delegation to circulate at the UN Assembly a proposal for UN-sponsored peacekeeping forces. While the idea to establish such a force had not originated with Pearson, he worked closely with UN Secretary-General Dag Hammarskjöld to negotiate the actual arrangements. Pearson carefully drafted resolutions designed not to offend the principal parties involved yet attract sufficient support from the Assembly. By placing UN forces between the invaders - British, French and Israeli - and the Egyptians, the new United Nations Emergency Force (UNEF I) was able gradually to improve conditions for promoting peace in the Middle East. UNEF I stopped the fighting from spreading, coaxed the parties involved to cease hostilities and enabled Britain and France to extricate themselves from the situation. UNEF's success meant that, since 1956, many more contingents of forces have been deployed to keep the peace in many parts of the world. Pearson's effort to implement peacekeeping forces is the most salient example of his effort to mediate a gradual improvement in world order. But his eager acceptance of other 
mediator roles for Canada during many other crises similarly stemmed from an underlying belief in the necessity of bringing about gradual change in world order through mediation and compromise, not revolution, deterrence or war.

Not surprisingly, there is now a widespread assumption that the idea to establish peacekeeping forces originated with Lester Pearson, partly because of conflicting interpretations of the crisis at the UN. He wrote in his memoirs that he "brought up" the possibility of an emergency UN force and, in an earlier address, claimed he thought it necessary that the UN set up some kind of peacekeeping force. ${ }^{32}$ Pearson's ready espousal of the idea and his role in persuading the American State Department to draft the resolution that he co-sponsored at the UN, indicate that peacekeeping forces were, in a sense, his idea. According to John Holmes, however, Anthony Eden and Selwyn Lloyd had spoken of the need for such a force in the Middle East when they visited Ottawa at the beginning of 1956, but "everyone had been talking about it without being specific" at the UN. ${ }^{33}$ Interviews conducted later by Peter Stursberg indicate that John Diefenbaker first mentioned the idea during a foreign affairs debate in the Canadian Parliament. Moreover, according to Geoffrey Pearson, an unknown person first proposed the idea even earlier during the Korean War. ${ }^{31}$ It seems many people had the idea at the same time (including the editors of The Globe and Mail who claimed that Pearson had taken up an idea their newspaper had proposed in 1951). ${ }^{35}$ All these claims to authorship lead to the conclusion that, whereas Pearson did not first conceive of the UN peacekeeping forces, he deserves praise for putting into practice an idea whose time had come.

\section{To Strengthen Internationalism}

Lester Pearson often referred to international co-operation for peace as the most important aspect of national policy. ${ }^{30}$ He used the short terms "participatory internationalism" and "internationalism" for the policy of maintaining and strengthening world peace as a principal objective of Canada's national policy. ${ }^{37}$ In Pearson's view, adherence to the concept of participatory internationalism required that "we always ask ourselves not only 'What kind of a Canada do we want?' but 'What kind of a world do we want?"' For Pearson, "this world view was consistent with a proper regard for our own interests" because "nationalism and internationalism were two sides of the same coin." ${ }^{\prime \prime s}$

This strong belief led Pearson to argue that Canada should not be afraid of commitments but activist in accepting international responsibilities. ${ }^{39}$ This oft-repeated theme proved not to be just rhetoric. His actions demonstrated a commitment to working for world peace under the auspices of international institutions such as the UN, the Commonwealth and NATO. In addition to his efforts to mediate crises through 
these institutions, Pearson was lauded for helping to broaden membership of the UN in 1955 by introducing a "Package Deal" to allow in new members. He was also credited for reinventing the Commonwealth because in 1949 he worked on the formula allowing the new republic of India to remain in the Commonwealth. In addition, he was praised for his seminal report on international development for the World Bank in $1968 .^{*}$ These many efforts to promote internationalism, by supporting international institutions, were widely respected in North America at a time when after the failure of the League of Nations, public faith in the power of international organisations to ensure peace was much less commonplace. Now multilateral efforts through international institutions in order to avert potential and actual conflict are a matter of course; in the 1940s and 1950s, however, Pearson's ideas about participatory internationalism were perceived to be courageous and pathbreaking.

\section{To Support Collective Security}

According to John Holmes, collective security - the creation of a system designed to preserve peace among its members - was the aim of policy in 1945. Collective defence was also an agreement among countries, in this case to defend the group against an outsider. ${ }^{42}$ Once again, Pearson put his own stamp on how the concepts were put into practice. When it seemed to him that the collective security system of the UN was floundering, he and other Canadian spokesmen "were among the first to enunciate the notion of a North Atlantic alliance, " or what is now called NATO. ${ }^{+3}$

Representatives from Western Europe and the United States agreed to the concept of a regional military alliance as a system of collective defence against the Soviet Union. Pearson, on the other hand, while clearly aware of the "dangers of Communism," felt such an alliance should attempt other means of fostering collective security. NATO could not replace the UN, but would be a short-term solution to the problem of Russian intransigence. ${ }^{4:}$ Consequently, Pearson worked to incorporate an article into the NATO treaty that urged member nations to work together on economic and cultural as well as military goals. Article 2, "the Canadian article" was included, despite high-level American opposition, but for decades NATO remained a collective defence arrangement. Pearson was later forced to conclude that the support for Article 2 had been insufficient, and continued his efforts to make the UN an effective collective security agency.

Despite his disappointment over Article 2, Pearson continued to support Canada's NATO commitments. As leader of the Opposition, and later as prime minister, he fundamentally rejected abandoning Canada's role in NATO in favour 
of neutrality. As he characteristically explained:

I know that there are many faults, and some dangers, in U.S. policy, but I think also that there is a basic difference between the principles that underlie its policy and those which determine that of the Communist imperialist system of the Soviet Union. Recognizing as I do, that difference, I cannot believe that abandonment of our present policies for complete neutrality would be a constructive step in the interests of peace. I think that we should continue to associate ourselves as closely as possible with the United States, the United Kingdom, France and other North Atlantic countries, but that we should direct all of our activities and policy inside this association to the maintenance and strengthening of peace and the ending of the cold war in a way which would make the present system of defence, through huge armaments, unnecessary. ${ }^{45}$

Pearson believed in preserving collective security - and collective defence - but not in promoting neutrality or non-alignment. He believed the concept of collective security implied a commitment to the use of force under the auspices of the UN, or NATO while peacekeeping forces came to be seen as "a step in the right direction in putting international force behind an international decision."

\section{Be Flexible and Pursue Quiet Diplomacy}

Friends and acquaintances of Pearson often remarked upon his ability to feel his way pragmatically and to obtain compromises and engage in give-and-take bargaining. ${ }^{+}$According to a journalist who often reported on Pearson's activities:

Possibly being a Canadian and accustomed to compromise Pearson at the United Nations did not regard compromise as a dirty word. When acceptable compromise didn't materialize he would fly kites sent up anonymously in the bars or corridors of the UN or in the press - to see what give-and-take might be available. Often some major country thought them great ideas and bagged them as their own, but Mike liked it that way. ${ }^{48}$

Pearson tended not to describe his negotiating style but often referred to the necessity for flexibility in foreign policy-making. He firmly believed that smaller countries, and even larger ones, were often only able to react to world events; a foreign policy, therefore, that was flexible and reactive was wiser than a policy that laid down firm principles. ${ }^{4}$ According to Pearson, 
If flexibility in the conduct of foreign policy is essential for Canada, it is unwise, then to lay down dogmatic priorities and postulates. This is especially true at a time of rapid and cataclysmic change, of the sudden emergence of international problems not even conceivable ten years before. In contemporary foreign policy, more than in most things, today's wisdom can quickly become tomorrow's folly. ${ }^{50}$

In addition to advocating flexibility in Canada's approach to international affairs, Pearson also recommended quiet diplomacy. In his view, quiet diplomacy meant that efforts to influence other nation's decisionmaking processes should use private persuasion, rather than public criticisms and suggestions." Apparently, Pearson considered quiet diplomacy especially useful for fostering a stable CanadaU.S. relationship, a view that incited many to criticise his government for failing to take a public stand against American aggression in Vietnam. In a letter replying to an appeal by hundreds of University of Toronto professors for the government to dissociate itself from the Vietnam war, Pearson wrote,

Confidential and quiet arguments by a responsible government are usually more effective than public ones. Too many public declarations and disclosures run the risk of complicating matters for those concerned. The more complex and dangerous the problem, the greater is the need for calm and deliberate diplomacy. ${ }^{52}$

Pearson's commitment to quiet diplomacy was also demonstrated throughout his career. He resorted to criticising publicly another country only once. During a convocation address at Temple University, Philadelphia, in 1965, he criticised President Johnson for the bombing of Vietnam. ${ }^{57}$ In this case, however, he seems to have considered the circumstances to be exceptional and to have spoken only after his government had made great private efforts to influence the Americans. ${ }^{5+}$ Otherwise, however, Pearson remained a strong proponent of diplomacy carried out behind closed doors. ${ }^{55}$

\section{From Themes to Guidelines}

This examination of the themes that recurred in Pearson's thinking indicates that he originated very few of the ideas he held to be important but that he excelled in consistently putting them into practice. While Pearson was not a systematic theoretical thinker, as was his colleague John Holmes, he clearly upheld a set of principles under most circumstances. Indeed, although he would have been the first to reject an attempt to formulate firm guidelines for managing Canadian foreign and defence 
policy, repeated references in his memoirs, speeches and correspondence suggest the following normative guidelines:

- Canada should play a role as a middle power on the international stage.

- Canada should seek every opportunity to mediate conflict in order to secure international peace.

- Canada should support international institutions and consistently act in order to promote internationalism and collective security.

- Canada should employ flexibility and quiet diplomacy in its interactions with other nations.

The themes and concepts that recurred in Pearson's thinking and manifested themselves in his lifelong behaviour, are consistent with the foundations of what is today called the liberal internationalist approach to foreign policy making. This is still the favoured doctrine among those who study Canadian foreign policy; indeed, there remains a great desire for a return, in effect, to the Golden Age of Canadian diplomacy as practised under Pearson. ${ }^{56}$ What are some reasons for this support (in Canada and abroad) for a liberal internationalist approach, no matter how vaguely defined it seems to be?

Pearson's ideas about foreign policy-making were derived from the liberal principles that he and most other Canadians absorbed. While Pearson was never fiercely partisan on behalf of Liberal Party principles, he admitted to having been brought up in an atmosphere of small "l" liberalism and to supporting the basic policies and principles of the Liberal Party.: The tenets of liberalism are nowhere written down or delineated, perhaps because in the 1940s and 1950s it was unnecessary to explain the nature of liberal thought as it had so extensively permeated the Canadian value system. It had become, as David Bell calls it, a kind of aura or ethos underlying all of North American political culture. ${ }^{58}$ This ideology had a strong impact on Pearson's approach to foreign policy-making. The final section of this paper considers the principles of liberal ideology and its relationship to Pearson's guidelines for Canadian foreign and defence policy.

\section{Liberal Ideology's Relationship to Pearson's Guidelines}

Three of the most important concepts of the liberal ideology, as it developed in Canada by the 1940 s and 1950 s, were equality, freedom and tolerance. ${ }^{59}$ In speeches to Liberal conventions and the public, Pearson usually referred to the importance of these to individuals;" more often, however, he spoke about their necessity among nations." In referring to the concept of functionalism - that is, by ensuring that Canada and the other middle and smaller powers had a voice and influence in 
international institutions - and by espousing the view that Canada had the right to act forthrightly as a middle power, Pearson assumed there was an emerging equality of nations; that each nation should be free to exert influence and take action on issues of particular concern to it; that the middle way was the path all moderate and tolerant nations such as Canada should espouse. ${ }^{\text {.2 }}$ As he asserted in his speech when receiving the Nobel Peace Prize, "Men normally live together in their own national society without war or chaos. So it must be one day in international society. If there is to be peace, there must be compromise, tolerance, agreement." ${ }^{n_{0.3}}$

Concomitant with the liberal faith in freedom, equality and tolerance was a pervasive cultural belief in the ability of humans to find a compromise solution to all types of problems. ${ }^{5+}$ This accounted for Pearson's unfailing resort to techniques of mediation and his deep conviction that "human problems, vast and complicated though they may be, are capable of solution." Even when he recognised that a final resolution to a problem was impossible, he frequently mediated acceptance by all parties of a temporary solution (e.g. UNEF I forces and Article 2 at NATO). According to Pearson's own research assistants, he "did not hesitate in accepting what had been achieved in immediate terms as a basis for a further attempt at the utopian when opportunity allowed."

The liberal ideology also held sacrosanct a belief in progress and the perfectibility of man and his institutions. ${ }^{67}$ Ever the optimist, Pearson similarly held inviolate the notion that the expansion of international institutions could only forward mankind's progress towards an ideal world. ${ }^{\text {th }}$ Even the signing of the NATO pact - a military alliance - led him to assert that the treaty was "a forward move in man's progress from the wasteland of his post-war world, to better, safer ground.... We are forever climbing the ever-mounting slope and must not rest until we reach the last objective of a sane and moral world." Pearson rejected the realist assumption that human nature impeded progress towards a better world; rather his vision foresaw the gradual yet inevitable onset of order and peace through the perfecting of international institutions.

In keeping with his opposition to realist and pessimistic assumptions about the inevitability of nuclear weapons proliferation, Pearson hoped for gradual progress toward world-wide and regional nuclear disarmament. As he explained in 1965 in a private lecture to members of Britain's Institute for Strategic Studies,

I was in Washington a few months ago. I spent an evening talking about a lot of things to some people who are pretty important in the present administration. I was surprised and somewhat disturbed to learn that there is a view in Washington that there is no use trying to do much about this, that it is inevitable, and that while we have to go through the motions and make all the usual declarations about the desirability of putting an end to nuclear weapons and especially to stop 
the proliferation of them, there is not only very little that we can do about it but, perhaps, in the long run it would not be a bad thing to have neighbours, who are on bad terms with each other having nuclear weapons as a deterrent on both sides to aggression. Just as you have a global nuclear deterrent now in the possession of nuclear weapons which can destroy the world, so, perhaps, you can have neighbourly nuclear deterrents to prevent neighbours from attacking each other. Well, that may be, but I must say I do not get very much comfort from a world organised on that basis. So we should be very worried at the moment about the lack of progress in this field. ${ }^{70}$

Pearson's emphasis on promoting gradual progress and reform, consistent with the principles of internationalism and collective security, also belied a preference for making gradual modifications in the existing world order. He sought a modest, not revolutionary, redistribution of political and economic power. The extent to which Pearson held to liberal values of progress, and the eventual perfectibility of institutions, is aptly illustrated by the following statement:

I felt then, as I do now, that the growth of the United Nations into a truly effective world organization was our best, perhaps our last, hope of bringing about enduring and creative peace if mankind was to end a savage tradition that the strong do what they can and the weak suffer what they must. With all its weaknesses, which soon became clear but which, after all were only those of its member states and the system of international anarchy in which they had to operate, the United Nations was at least a foundation for a new world on which we could build.?

While many realists continued to denigrate the idea of a successful UN system, Pearson admitted to the UN's frailties but had faith that these would eventually be overcome.

Finally, liberal ideology engendered the idea that although conflict in human affairs is inevitable, harmony of interest could be obtained through the use of rationality and enlightened self-interest. ${ }^{2} \mathrm{He}$ assumed all nations would ultimately want to establish relations of "friendship, goodwill, and agreement with other countries so that insistence on the use of force" was not required. "Pearson never could understand "why men with generous and understanding hearts, and peaceful instincts in their normal individual behaviour can become fighting and even savage national animals." He believed one solution was to increase communication and contact between fighting groups. ${ }^{74}$ Flexibility and quiet diplomacy were the principal methods of increasing communication that Pearson promoted. Their use indicates a profound belief that rational and self-interested discussion would eventually obtain harmony of interest. 
To conclude, the themes that recur in Pearson's thinking can be summarised in a few simple guidelines for Canadian foreign policy-making. Pearsonian policies earned accolades on the world stage and helped found the theory of liberal internationalism that still dominates discussion of Canadian foreign and defence policy. His convictions and concepts were not strikingly original but, rooted in a liberal way of viewing the world, they formed the foundation for a widely shared approach to developing and implementing Canadian foreign policy.

\section{Notes}

1. George Ignatieff cited in Peter Stursberg, Lester l'arson and the American Dilemma (Toronto: Doubleday, 1980) 72 .

2. For an analysis of the prime minister's accomplishments in domestic politics, see Robert Bothwell, Pearson: His Life and World (Toronto: McGraw, Hill, Ryerson, 1978). Since the focus here is on Pearson's principles of liberal internationalism, a detailed account of the historical events of Pearson's era and his achievements is not provided. For excellent accounts, see Geoffrey Pearson, Seize the Day: Lester B. Pearson and Crisis Diplomacy (Ottawa: Carleton University Press, 1993) and John English. The Worldly Years: The Life of Lester Pearson 1949-1972 (Toronto: Alfred A. Knopf, 1992).

3. In the literature, the liberal internationalist school is also variously referred to as Pearsonian internationalism, internationalism, multilateralism and Canadian idealism.

4. In particular, see Michael K. Hawes, Principal Power, Middle Power, or Satellite? (Toronto: York Research Programme in Strategic Studies, 1984) 3-7; David B. Dewitt and John Kirton, Canada as a Principal Power (Totonto: John Wiley \& Sons, 1983); and John Holmes, The Better Part of Valour: Essays on Canadian Diplomacy (Toronto: McClelland \& Stewart, 1970) and Canada: A Middle-Aged Power (Toronto: McClelland \& Stewart, 1976).

5. This has been pointed out by many analysts including Hawes 4; Dewitt and Kirton 17; Holmes, The Better lart of Valour 14.

6. Department of External Affairs, Foreign Policy for Canadians (Ottawa: Queen's Printer for Canada, 1970) 8.

7. Interview with Geoffrey Pearson by Stursberg 57.

8. The author would like to thank Geoffrey Pearson for according access to some relevant documents in the restricted L.B. Pearson Papers at the Public Archives of Canada /hereafter PACl; in particular the records of cabinet meetings and some formerly classified transcripts, notes and memoranda were obtained under the Access to Information Act from the Privy Council Office and the Department of National Defence, Directorate of History [hereafter DHist]. Permission to peruse classified files from the Department of Foreign Affairs and International Trade was also granted after these files were screened by foreign service officers and the author obtained security clearance. For a more comprehensive analysis of Lester Pearson's approach towards defence policy issues, nuclear weapons and NATO, see Erika Simpson, Canadian Leaders on NATO and the Bomb: Defenders Confront Critics (forthcoming). 
9. See Ibid. See also Richard Little and Steve Smith, Belief Systems and Int'rnational Relations (London: Oxford University Press, 1988); Albert S. Yee, "The causal effects of ideas on policies," International Organization, Winter 1996.

10. Notably, one of the clearest expositions of the main tenets of liberal internationalism renders the theory a coherence and clarity that even its practitioners did not admit to having. Dewitt and Kirton coin conceptual labels and terms to refer to the general ideas underlying liberal internationalism (e.g."distributive internationalism." "mediatory middlepowermanship" and the "diplomacy of constraint") 17-28. The themes described here, are distilled from Pearson's own thinking, and refer only to those terms that Pearson himself used. Consequently, the ideas may lack the conceptual clarity and theoretical force that characterises some explanations of liberal internationalism, but the reward is a greater appreciation of Pearson's philosophical contribution.

11. Peyton V. Lyon and Brian W. Tomlin, Canada as an International Actor (Macmillan: Toronto, 1979) 11; John Holmes, The Shaping of Peace (Toronto: University of Toronto Press, 1979) Vol. 1236.

12. Pearson did not coin the term middle power. According to Holmes, The Shaping of Peace 236. Mackenzie King made first reference to Canada as a power of middle size in a speech to the Commonwealth prime ministers in May 1944.

13. For example, see the speech he made in 1951 entitled "Canadian Foreign Policy in a TwoPower World" in his Words and Occasions (Toronto: University of Toronto Press, 1970) 101 and his lecture in Peace in the Family of Man (Toronto: Oxford University Press, 1969) 24.

14. Lester Pearson, Mike (Toronto: University of Toronto Press, 1973) Vol. II 29.

15. Pearson, Mike Vol. II 29; Holmes, Canada: A Middle-Aged Power 34.

16. Holmes, Canada: A Middle-Aged Power vi.

17. For the view that middle power originally denoted size and ability to contribute to the United Nations, see Ibid. 34-35. For an example of Pearson's implicit assumption that a middle power required economic strength, see his comments in Mike, Vol. Il 29.

18. For instance, see Holmes's admission that the term became ambivalent "perhaps to the point of being meaningless" as it was increasingly used to describe intermediary countries such as Norway, Ireland and Tunisia, which were hardly medium in resources or population, and a country like India, which although enormous in population was neither economically or militarily a great power. Holmes, Canada: A Middle-Aged Power 34-35.

19. Perhaps the shortest definition Holmes offered was that "middle powers are middle powers because they are weaker, not because they are more virtuous." Canada: A Middle-Aged Power 37 . Probably the best treatment of the concept of middle power is found in this same volume, 33 .

20. David Mitrany first conceived of functionalism as a method of promoting peaceful integration in A Working Peace System: An Argument for the Functional Development of International Organization (London and New York: Royal Institute of International Affairs, 1946). The term came to refer to a process of organising international activity according to functional or technical interests. Functionalism was intended to help to circumvent state sovereignty and depoliticise certain areas. The Canadian definition, however, was different: representation in decision-making on the basis of one's contributions or ability to contribute to the matter at hand. For further analyses of the 
importance of functionalism in Canadian foreign policy, see Michael Tucker's description of its origins in Canadian Foreign Policy 6-7; A.J. Miller, "The Functional Principle in Canada's External Relations," International Journal 35 (Spring 1980): 309-28; and Tom Keating, Canada and World Order (Toronto: Mcclelland \& Stewart, 1993) 251.

21. Keating, Canada and World Order 28-30.

22. House of Commons, Debates, 9 July, 1943, 4558 and cited in J.L. Granatstein, Canadian Foreign Policy Since 1945: Middle Power or Satellite? 2nd ed. (Toronto: Copp Clark Publishing, 1973) 12.

23. Pearson, Mike (Toronto: University of Toronto Press, 1972) Vol. 1215.

24. Ibid. 267; Holmes, Canada: A Middle-Aged Power vii.

25. Holmes, "Canadian External Policy," International Joumal 18 (Spring 1963): 137.

26. For evidence that this was the motive of the diplonats under Pearson, see Ibid. 3 and Pearson, Mike Vol. 1215. See also Holmes's similar admission in a later volume that the concept of functionalism was also used to "allay the fear of the great powers that if they shared any of their power with the smaller states that they would eventually be forced to surrender all control." The Shaping of Peace, Vol. 1, 38.

27. Dewitt and Kirton 20-21; Tucker 6; and Hawes 5.

28. For further discussion, see Canada: A Middle-Aged Power vii and Keating, Canada and World Oriler 32

29. For the view that the mediator role was often imposed upon the middle powers, see Ibid. 36 .

30. For example see Pearson, Mike, Vol. II 276.

31. lbid. 244 .

32. Pearson, Mike, Vol. II 245; Peace in the Family of Man 14.

33. Transcript of interview of Holmes in Stursberg 144.

34. Transcript of interview of Geoffrey Pearson, Ibid. 144-45.

35. See the claim made in The Globe and Mail editorial (3 November 1956) and excerpted in Granatstein 85-86.

36. For example, see Pearson, Mike Vol. I 294; Mike Vol. II 32 and the description by Peyton Lyon of Pearson's lectures to students after his retirement in Stursberg 309.

37. Pearson, Mike Vol. II 32.

38. Ibid. 32 .

39. For example, see Mike Vol. I 294 and Vol. II 31.

40. For the details of Pearson's role in these initiatives see Bruce Thordarson, Lester Pearson: Diplomat and Politician 219-22 and Stursberg 112.

41. One diplomat's comments about Pearson's key role in establishing the Columbo Plan (a scheme to assist the development of the Commonwealth states of South Asia by using tax dollars from contributing nations) provides merely one example of the state of public opinion, in the 1950s, regarding international institutions. According to diplomat Arnold Smith, Pearson deserved a great deal of credit for setting in place what was seen to be "a pretty radical doctrine at that time." Transcript of interview of Arnold Smith in Stursberg 116.

42. Holmes, The Shaping of Peace Vol. II 5.

43. Pearson, Mike Vol. II 36; Holmes, "Canadian External Policies since 1945" 137. 
44. This interpretation of Pearson's motives for supporting NATO's establishment was offered by Geoffrey Pearson in an interview in Stursberg 57 and it is corroborated by Pearson, Mike Vol. II 36.

45. PAC, Leader of Opposition Correspondence Series, MG 26 N2, Vol. 88, File "Neutralism," Office of the Leader of the Opposition, sample letter from Mr. Pearson to enquiries regarding his views on the theory of neutralism as advocated by James. W. Minifie, June 1960 , 1. For more on Pearson's views on the merits of not withdrawing from NATO, but working within it to support collective security, and continuing to fully support the United Nations, see MG 26 NZ, Vol. 54, File 830, letter to Franc R. Joubin, 21 February 1961 and House of Commons, Debates, 28 March 1961, 3446.

46. Pearson, Mike Vol. II 274; see also Holmes's criticism of the indiscriminate use of the term collective security in Shaping the Peace Vol. II 5.

47. See Arnold Smith's references to the way Pearson "felt his way pragmatically" and George Ignatieff's comments about l'earson's "fundamental pragmatism" in Stursberg 152, 72.

48. Norman Smith, "Pearson, people and press," International Joumal 29.1 (Winter 1973-74): 12.

49. For example, see Pearson's comments on the necessity for flexibility in Mike Vol. II 30, 34. Further evidence of Pearson's belief in a flexible approach to foreign policy making, is seen in his reaction to Trudeau's instigation of a foreign policy review. At the time, Pearson was a professor at Carleton University and he used his graduate seminars as a forum to react angrily to Trudeau's implicit criticism of the ad hoc way Pearson had conducted foreign policy-making. Indeed, Pearson felt so strongly about the ill-advised approach Trudeau was taking that he arranged to meet privately to discuss the disadvantages of formulating firm priorities in Canadian foreign policy. See the comments by Mitchell Sharp on this interview in Stursberg 310.

50. Pearson, Mike, Vol. II 31.

51. Ibid. 34.

52. Letter by Pearson excerpted in Granatstein 30.

53. For a detailed account of the speech and Pearson's general approach toward Americans during the Vietnam War, see English 358-380.

54. For evidence see the interviews with Paul Martin, Geoffrey Pearson and Lubor Zink in Stursberg 216-224.

55. The only other incident, reportedly, when Pearson made his criticism public was much earlier, in 1951, during a speech he made to the Empire and Canadian Clubs. His reference to what he considered to be an objective fact - that the days of smooth and easy relations with the United States were over - was seized upon by the press as a vigorous criticism of the United States. Pearson, however, interpreted his comment to be a balanced and objective statement of reality. An examination of Pearson's actual comments within the context of his overall speech substantiates this claim and, therefore, it seems warranted to claim that Pearson held to the tenet of quiet diplomacy throughout his entire career, barring one occasion, namely his speech at Temple University. See "Canadian Policy in a Two-Power World," Words and Occasions 101.

56. For the view that it remains the dominant perspective see Hawes 4 and Dewitt and Kirton 17. For analyses of the desire to return to espousing liberal internationalist principles in Canadian foreign policy see, for example, Escott Reid, "Canadian Foreign Policy, 
1967-1977: A Second Golden Decade" in Granatstein 185-89; David A. Lenarcic and Dean F. Oliver, "Quiet Diplomacy is Ottawa's best tactic," The Globe and Mail, [Torontol 7 August 1997.

57. Pearson, Mike Vol. II 45.

58. David Bell, "Political Culture in Canada," Canadian Politics in the 1980s, eds. Michael Whittington and Glen Williams (Agincourt, Ontario: Methuen Publications, 1981) 115. See also Denis Stairs's seminal work on the political culture of Canadian foreign policy, which has a broader relevance to this article: "The Political Culture of Canadian Foreign Policy," Canadian Journal of Political Science 15.4 (December 1982).

59. Frank Underhill, "Some Reflections on the Liberal Tradition in North America," In Search of Canadian Liberalism (Toronto: Macmillan Company of Canada limited, 1960) 5.

60. For instance, Pearson saw fit in one speech to express at length his firm belief in the importance "the middle way placed on the integrity and worth of the individual in society and the individual's right to manage his own affairs and speak his own mind." See "The Implications of a Free Society," Words and Occasions 91.

61. For example, see his speech at the 1945 San Francisco conference excerpted in Words and Occasions 62; his speech upon receiving the Nobel Peace Prize excerpted in Mike Vol. II 278; and his speeches "Before the UN 1963" and "At the Atlantic Award Dinner 1966" in Words and Occasions 219, 257.

62. On the other hand, one could argue that Pearson's ranking of countries into a hierarchy of great, middle and small powers was indicative of his adherence to conservative or Tory notions of hierarchy and authority. If one examines Pearson's objectives, however, (and his colleagues in the Department of External Affairs' purpose) for employing the concepts of middle-powermanship and functionalism, it becomes evident that the object was to increase the influence of the weaker nations in international institutions which were, at that time, dominated by the superpowers.

63. Pearson's speech upon receiving the Nobel Peace Prize is excerpted in Mike Vol. II 278.

64. Charles Taylor, The Pattern of Politics (Toronto: McClelland \& Stewart, 1970) 2-3.

65. Pearson, "The Implications of a Free Society 1949," Words and Occasions 91 ; see also his "Address to the Ontario Liberal Association 1953," Ihid. 123.

66. J.A. Munro and A.I. Inglis, "The Atomic Conference 1945 and the Pearson Memoirs," International Journal 29.1 (Winter 1973-74): 100.

67. Frank Underhill, "Canadian Liberal Democracy 1955," In Search of Canadian Liberalism 228.

68. Pearson, Mike Vol. II 35.

69. Pearson in a speech entitled "On Signing the NATO Treaty," Words and Occasions 89.

70. DND, DHist, Chairman, Chiefs of Staff and Chief of Defence Staff, The Raymont Collection, 73/1223, Series One, File 848, "Canadian Policy-Foreign and Domestic," Excerpts from Prime Minister Pearson's Private Lecture to the Institute for Strategic Studies, London, England, 16 June 1965, 5.

71. Pearson, Mike Vol. II 283.

72. Taylor 3; Underhill 228.

73. Pearson, Mike Vol. II 32 .

74. Pearson in his speech accepting the Nobel Peace Prize excerpted in Mike Vol. II 278, 277. 